\title{
Nosotros, los que quedamos atrás Migración salvadoreña a través de la fotografia de niños y niñas en Arcatao y La Chacra.
}

Por: Heather Bradley

\section{Migracion, niños y fotografía participativa en El Salvador}

$\mathrm{E}$ campo de los estudios sobre emigración ha crecido enormemente en los últimos años, yendo más allá de los análisis sobre factores de "empuje" y "atracción" en una dirección a un saber interdisciplinario que examina el punto de intersección entre las dimensiones socio-culturales, económicas y políticas de migración, y los problemas que conlleva.

En el caso de El Salvador, tal multiplicidad se refleja en la respuesta que la emigración ha acumulado, no solamente de parte de las comunidades locales de emigrantes sino también de las entidades académicas, políticas, grupos de activistas y aún de las gubernamentales, tanto en El Salvador como en el exterior. El creciente rango y número de personas interesadas en el fenómeno atestiguan el aumento de la diversidad de depositarios o personas afectadas, cuyos intereses, preocupaciones o necesidades se encuentran de alguna manera vinculados a los intercambios transnacionales que personifica la emigración salvadoreña contemporánea.

Como estudiante universitaria en Washington DC., comencé mis estu-

\footnotetext{
**Nota importante

La mayoría de las fotos tiene una descripción correspondiente escrita a mano por cada niña o niño fotógrafo. En esta versión preliminar, sin ningún diseño gráfico, se evita incluir imágenes y se anotan textos en notas de pie de página. La versión final incluirá las imágenes de las fotos y los textos de las descripciones originales.
} 
dios e investigación sobre migración en el 2003, dentro del aula, y también con la comunidad salvadoreña más grande en el área del DC. Ya más familiarizada con mis estudios sobre el tema, con mi tiempo en El Salvador y con una creciente interacción con la comunidad de la diáspora, me di cuenta de la enorme discrepancia entre lo que estaba viendo y escuchando (tanto en El Salvador como en Estados Unidos) y lo que estaba leyendo.

En ese momento existía literatura nominal disponible, que examinaba específicamente cómo la emigración masiva de jóvenes de El Salvador estaba afectando social, cultural y personalmente a los numerosos hijos que los emigrantes estaban forzados a dejar en el país. Había escuchado testimonios de madres salvadoreñas en los Estados Unidos, describiendo lo difícil que era dejar a los niños o la alienación que sienten cuando vienen a los Estados Unidos después de varios años de separación. Similarmente, en El Salvador, la brecha en el continuo de edad, entre los envejecidos abuelos que luchaban por criar a sus nietos ante la ausencia de sus propios hijos, los padres, era palpable a simple vista.

Considerando que se estima que cerca de un quinto de la población reside fuera del país y que ellos sientan la habilidad de proveer a sus familias como la principal razón para emigrar, existe un increíble número de niños en El Salvador que ha sido dejado sin uno o ambos padres; muy a menudo son dejados al cuidado de los abuelos u otros miembros de la familia. Las experiencias de estos niños en cuanto a emigración son cruciales, no solo para entender comprensivamente la migración, sino también para imaginar el futuro: cómo evolucionará la migración en El Salvador y la dependencia de las remesas del receptor pobre en el país.

No obstante su inclusión ocasional en las estadísticas como beneficiarios de remesas, los niños no son reconocidos como sujetos dinámicos dentro del fenómeno migratorio, mucho menos como niños cuyos derechos humanos están siendo violados. Además, cuando la literatura se refiere a ellos, la mayoría de veces analiza su posición como una tercera parte. Raramente los análisis abordan la experiencia de estos jóvenes más allá de los trillados temas de "la desintegración familiar", la transculturización o su presunta propensión a participar en el crimen organizado.

Así, esta investigación y el proyecto "Voces y Vistas: Niños de la Diáspora Salvadoreña" nacieron del silencio de este grupo de jóvenes, como consecuencia no únicamente de su estatus de niños, sino también de su posición social como clase baja, incluyendo su pobreza material. Por medio de un análisis crítico de las propias fotografías de los participantes, asî como de sus escritos $y$ testimonios durante el tiempo que estuvieron en calidad de miembros y co-hacedores del proyecto, este 
documento nos sirve para hacer escuchar sus voces.

"VOCES Y VISTAS": PRÁCTICA CRÍTICA, INVESTIGACIÓN CRÍTICA

Los programas de fotografía participativa y alfabetización por medio de la fotografía se han vuelto muy populares en los últimos años. Como un medio de "otorgar voz" a la gente y comunidades silenciadas alrededor del mundo, las cámaras parecen haberse convertido en el nuevo accesorio transnacional de los pobres del mundo. Sin embargo, estos programas dejan mucho que desear, especialmente para esos niños o personas que participan en ellos y sin quienes estos proyectos no existirían. Teniendo esto en mente, "Voces y Vistas", como programa, intenta resistir el tradicional método de educación bancaria, estimulando a sus participantes (por medio del currículo y los métodos de instrucción) a pensar críticamente (Freire 2003) sobre la emigración y su lugar dentro de ella. El proyecto va más allá del compromiso con lo investigativo, dedicándose por sí mismo a una práctica crítica mediante la cual los participantes, así como las personas que han sido tomadas en cuenta en el estudio, se hallan también involu- cradas y colaborando por medio de sus imágenes.

"Voces y Vistas" está dedicado, sobre todo, a la mediación y exposición crítica del trabajo de los niños. Muchos programas similares asumen que el suministro de tecnología fotográfica es por sí mismo un proceso democrático, mediante el cual los pobres o subordinados están aptos para representarse por sí mismos como ciudadanos-sujetos. Esta asunción ha conducido a menudo a una mala apropiación del trabajo de los participantes. En estos casos, una "colonización" de la imagen trabaja ultimadamente para reforzar la localización periférica de los participantes del programa y purga su trabajo de su política, sentido y valor original (Giroux 1994 y Salomón-Godeau 1991).

El fin último de "Voces y Vistas" es el uso de la cámara como una herramienta narrativa de estos jóvenes como practicantes críticos, en su condición de artistas y sujetos, que se comprometan con un mecanismo por medio del cual puedan volver atrás y conversar con esas fuerzas que, no solamente engendran las condiciones bajo las cuales viven, sino que, además, parecen hablar en su nombre, al mismo tiempo les niegan su voz.

\section{Nuevas voces: "voces y vistas", el servicio jesuita para migrantes y la Universidad Centroamericana José Simeón Cañas}


de la Universidad Centroamericana José Simeón Cañas (UCA) y bajo los auspicios del Servicio Jesuita para Migrantes. A pesar de la marcada diferencia de ambas comunidades, en términos de ubicación, una urbana y otra rural, han sido testigos de las altas tasas de emigración en ellas mismas durante las dos últimas décadas, desarrollando sus propias formas de lidiar con sus efectos y salir adelante.

Aún cuando cada comunidad tiene su propia historia y circunstancia contemporánea, el examen de las fotografías de los participantes de ambos lugares revela un número de temas comunes, los cuales forman el marco teórico de este documento. Estos temas son: la decisión y motivación por emigrar, la familia local y transnacional, el rol y significado de las remesas, sus propias identidades $y$ formas de ver la vida como niños de la diáspora salvadoreña.

La presentación de cada una de estas áreas conceptuales será de indole comparativa, examinando imágenes desde cada uno de los sitios del proyecto, situándolas en sus respectivos contextos históricos y sociales. A pesar de la necesaria incorporación de fuentes académicas a este documento, intento representar y privilegiar las opiniones de los niños por medio del análisis, entrelazando sus propios textos, escritos a mano, y sus testimonios.

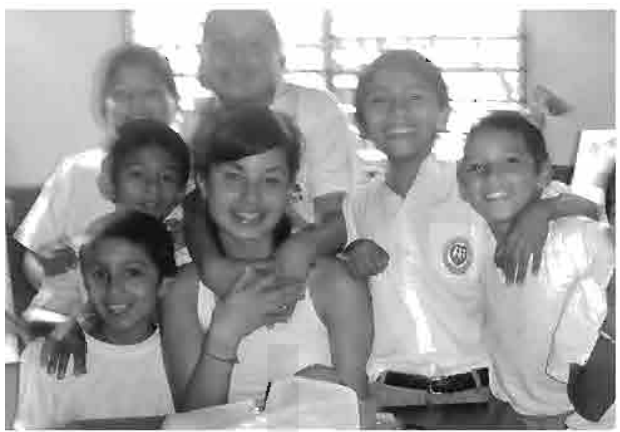

Heather con niños de La Chacra.

El documento culmina con un examen general del estado actual de los niños, y algunas sugerencias para futuras políticas e investigaciones que servirán para comprender mejor sus situaciones, así como para valorar sus derechos como niños y ciudadanos-sujetos.

\section{La Chacra: escapando de la guerra, escapando de la pobreza}

La comunidad de La Chacra se encuentra al pie del cerro San Jacinto, una colina situada en las afueras del San Salvador metropolitano y tema recurrente de muchas leyendas e imágenes folklóricas salvadoreñas. Sin embargo, en medio de este idílico lugar y el pesado tráfico del boulevard, existe una enorme comunidad escondida. Invisible desde la calle, descansa en una extensa área de tierra hundida, entre la base de la colina y el camino. Es un extenso promontorio de casas, hechas de hojas de aluminio y materiales de desecho, que se extiende en varias direcciones, en forma desordenada y sin ninguna planificación. 
La comunidad, fundada hace casi 50 años, creció durante la guerra civil, cuando gente de las zonas rurales aledañas comenzó a escapar hacia la zona urbana. Una gran parte de la comunidad es originaria de San Vicente (entre otras áreas rurales cercanas al área metropolitana); los vicentinos Ilegaron a la capital al intensificarse el reclutamiento de civiles por parte de los grupos paramilitares y la guerrilla, en momentos en que el conflicto se tornó más violento. Una vez que llegaron, disponían de escasos recursos, aunque algunos tenían parientes en la capital que hicieron lo que pudieron para darles refugio y seguridad a su familia. A pesar de los billones de dólares vertidos por Estados Unidos. en el país por esa fecha, éstos fracasaron en ayudar a comunidades como La Chacra, donde, en cambio, la pobreza se reprodujo como hongos durante la época de la guerra (Repak: 1995:38).

Si bien desplazados por la guerra, la comunidad se politizó a medida que el conflicto se desarrolló, convirtiéndose en militantes (aunque difícilmente en combatientes) del Frente Farabundo Martí para la Liberación Nacional (FMLN).

Pero la violencia en La Chacra no terminaría con la guerra civil (1981-1992). Actualmente la comunidad es un hervidero de violencia, relacionado con pandillas y tráfico de drogas. La división literal entre la zona que pertenece a "la Mara

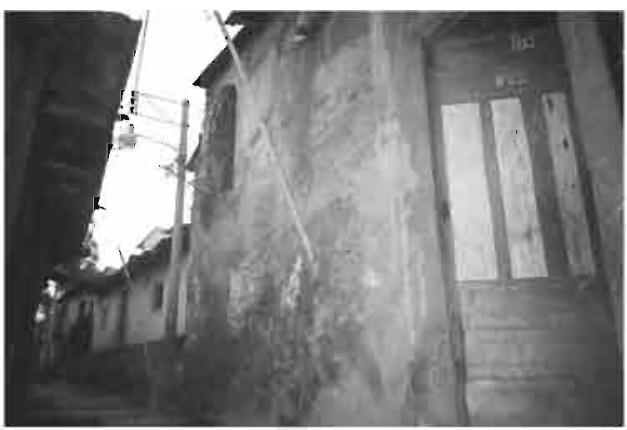

Vista una calle de La Chacra.

$18^{\prime \prime}$ y la que pertenece a la Mara Salvatrucha (MS) convirtió a la Chacra es un campo urbano de batalla. Oficialmente es parte de la "18", descle que un gran número de sus miembros fueron dejados en libertad varios años antes, retomando la comunidad de la "MS", zona famosa por las drogas, los homicidios y los robos. Según los residentes, la implementación del plan gubernamental "Super Mano Dura" no ha sido una política eficiente, ya que la violencia y el crimen organizado en La Chacra no sólo no se ha reducido, sino que, de hecho, ha continuado en ascenso desde su implementación ${ }^{2}$.

En cambio, las condiciones de violencia en la comunidad han sido mucho más aliviadas por medio de un extenso proyecto de revitalización a largo plazo, llevado a cabo por la Fundación Salvadoreña de Desarrollo y Vivienda Mínima de El Salvador (FUNDASAL), institución fundada por el grupo alemán, Kreditanstalt für Wiederaufbau (KFW). El proyecto en sí mismo busca satisfacer una variedad de necesidades de 
infraestructura básicas de la comunidad, especialmente la construcción de un muro de contención a lo largo del río sucio (Acelhuate) que atraviesa la comunidad, un sólido sistema de recolección de basura, la pavimentación de los caminos y la formalización de los derechos de propiedad sobre la tierra. A punto de completarse el proyecto, la comunidad (un conglomerado de 18 comunidades formales e informales) obtiene el nombre de "Los Manantiales"

El empleo en la comunidad y a su alrededor es escaso. Los pocos que trabajan lo hacen en "el centro" (un gran mercado al aire libre) o en un mercado cerrado cercano llamado "La Tiendona", famoso por las estafas, la violencia y el robo. Otros miembros de la comunidad tienden a trabajar en servicios de temporada, la venta informal de artículos comestibles y otros, o sobrevivir en variedad de contratos a

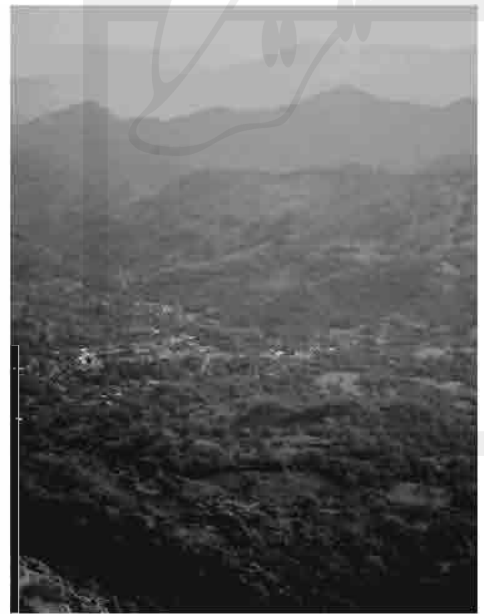

Vista panorámica de Arcatao

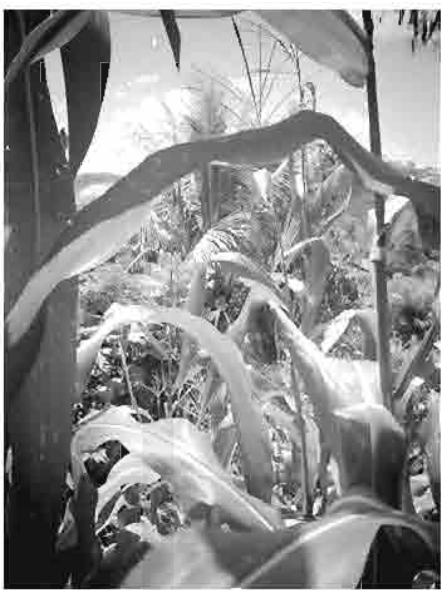

Plantación de Maíz, Arcatao

destajo como carpintería, pintura, etc. La carencia generalizada de seguridad, combinada con los altos niveles de desempleo y pobreza, crea un ambiente propicio para que los desesperados miembros de la comunidad pongan sus esperanzas en las posibilidades de "allá".

\section{Arcatao, de la repoblación de la post-guerra a la migración en masa}

A diferencia de La Chacra, Arcatao se localiza en las altas elevaciones del rural y noreste departamento de Chalatenango, en la frontera de El Salvador con Honduras. Es un pueblo pintoresco con una gran iglesia blanca en su punto más alto; es difícil imaginar este pueblo hace 20 años, prácticamente abandonado y en ruinas. Un centro de resistencia durante la guerra, Arcatao fue el escenario de innumerables atrocidades en contra de la población civil y grupos organizados, cometidas por entidades hondureñas y salvadoreñas. 


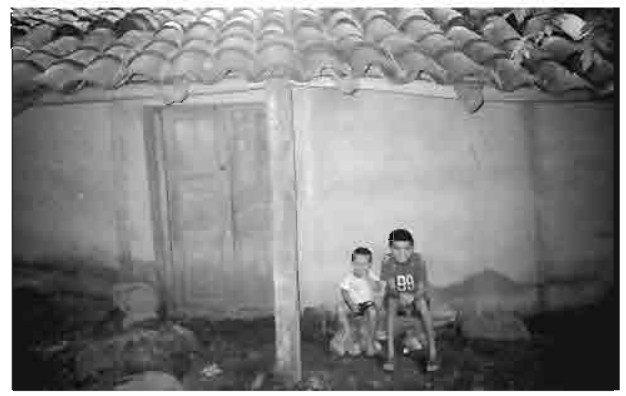

Ninos frente a su casa en Arcatao

En Arcatao, una de las "Comunidades Eclesiales de Base" (CEBES), comenzó a organizarse pacíficamente en los años 70 , al enraizarse la Teología de la Liberación en muchas comunidades campesinas. Con el incremento de la represión militar, sostenida por décadas, en contra de las "organizaciones popu-

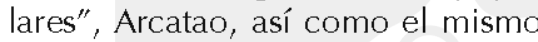
departamento de Chalatenango, se volvió progresivamente activo, tanto en los movimientos armados como en los no armados, en contra de la represión ejercida por el gobierno. La iglesia católica jugó un rol crucial en la organización de "las masas", ofreciendo apoyo a sus partidarios, especialmente la CEBES y denunciando públicamente al gobierno y la represión selectiva (Sobrino et al. 102).

El caos y la violencia que conmocionó Arcatao durante la época de la guerra están simbolizados en las experiencias del señor Pedro Alfaro Dubón, lisiado de guerra, cuyas historias resuenan como la mayoría de las historias de vida de los repobladores de Arcatao. Cuando niño, Pedro fue testigo de cómo su padre fue sacado de su casa por la guerrilla. El cuerpo de su padre nunca fue encontrado, pero su muerte está confirmada. Pocos años después de este suceso, el mismo Pedro fue reclutado a la fuerza por el ejército como niño soldado. Sin embargo, con el tiempo escapó y volvió a Arcatao. A su regreso, Pedro decidió unirse a la guerrilla, a la misma facción que mató a su padre cuando era niño; y peleó hasta ser impactado en la cabeza por una bala perdida, que lo dejó paralizado del lado izquierdo.

La violencia bélica terminó en 1992, con la firma de los Acuerdos de Paz, y la vida, literalmente, volvió a Arcatao. Los movimientos de repoblación culminaron en estos años, con el regreso de mucha gente desplazada que había sufrido durante las "guindas" (huidas del ejército), en los campos de refugiados, y en condición de asilados. Sin embargo, muchos nunca volvieron a sus hogares después del conflicto.

Nuevos hogares de bloques de cemento fueron construidos ${ }^{4}$, a fin de reemplazar las débiles casas de adobe o aquellas que habían estado habitadas por refugiados durante la ausencia de sus dueños. Las tierras se distribuyeron a tenedores individuales y un grupo de organizaciones locales, nacionales e internacionales trabajaron conjuntamente, a fin de proporcionar empleo y oportunidades culturales y sociales a los desmovilizados. Pese a los esfuerzos de acrecentar el 
desarrollo posterior al conflicto, la comunidad continúa dependiendo cultural y económicamente de la agricultura y artesanía tradicionales.

Mientras los hombres trabajan la tierra, la mayoría de días de la semana, las mujeres y los niños pafticipan en el cuidado $y$ la cosecha de sus tierras los fines de semana - por temporadas. Las mujeres de la comunidad también tienden a trabajar en pequeñas tiendas, comedores o en cooperativas establecidas durante el período de repoblación, en el cual el apoyo monetario y organizativo era más fácilmente logrado por tales proyectos de empleo ${ }^{5}$. Sin embargo, la carencia de oportunidades, la pobreza y el aislamiento geográfico de Arcatao tienen ya a muchos de sus jóvenes soñando con una vida en el "norte". como recurso a la aparente sombría perspectiva que enfrentan en sus propias comunidades.

\section{"Voces $y$ vistas" en La Chacra $y$ Arcatao}

La entrada del proyecto en ambas comunidades fue facilitada por la UCA y sus largas y estables relaciones con las comunidades jesuitas en ambos lugares. En La Chacra, el programa se introdujo en el Centro Escolar Fe y Alegría, apoyado por la Compañía de Jesús en El Salvador, y en Arcalao, por medio de la directiva parroquial, cuyo párroco es un sacerdote jesuita.

\section{La Chacra}

Comenzando a principios de Julio del 2005, el proyecto se rea-

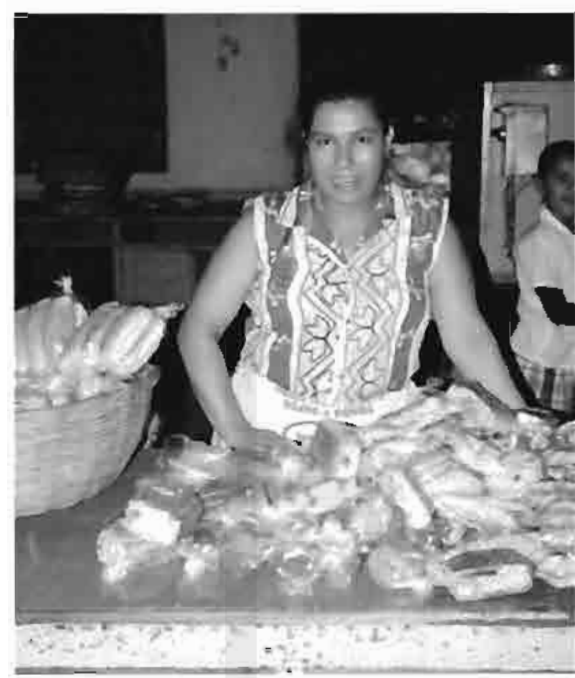

Señora con su producción de pan horneaco en Arcatao

lizó durante un periodo de cuatro semanas con 10 esiudiantes del lugar. Los participantes fueron seleccionados al azar, por parte de la sdministración escolar, entre aquellos estudiantes que reunían los dos requisitos para participar en el proyecto: tener uno o ambos padres residiendo actualmente en el extranjero y tener entre 8 y 14 años de edad.

Los estudiantes son oriundos de diferentes partes de La Chacra, especialmente de los barrios de Morazán, Amatepec y Santa María, así como unos pocos que viven a lo largo de la línea férrea. Todos son niños pobres, si bien los de Santa María se consideran que están mucho mejor que los de Morazán y Amatepec, mientras que los que viven en "la línea" (línea férrea) se cuentan entre los más pobres. 
Sus niveles de escolaridad oscilan del primero al sexto grado y lo conforman siete niños y tres niñas. Si bien se requería de una distribución equitativa entre ambos sexos (inicialmente se enrolaron en el programa 4 niñas y 6 niños), fue difícil para la escuela encontrar participación femenina voluntaria, esto aunado al retiro de una de las estudiantes a petición de su encargado.

La realización del programa se volvió, además, ocasionalmente problemático, debido a la escasez de aulas disponibles y a la imposibilidad de fotografiar en campo abierto por razones de seguridad de los niños. Por lo tanto, nuestras prácticas tuvieron que desarrollarse dentro de las instalaciones de la escuela y las composiciones de la mayoría de fotografías personales de los niños están también orientadas al hogar o a puerta cerrada.

A diferencia de la mayoría de niños, quienes tienen dificultad para adaptarse a un programa basado en el arte, donde existe el típico currículum de memoria de sus escuelas, estos niños hicieron la transición satisfactoria y rápidamente. La facilidad con la cual se involucraron al currículum fue posible por el hecho de que casi la mitad de la clase tenía acceso y exposición previa a la fotografía, tanto tecnológicamente como comercialmente y en desarrollo de film.

Su habilidad para comprender y manipular conceptos abstractos son también atribuibles al currículum de educación "integral" y a los métodos de enseñanza del Centro Escolar Fe y Alegría ${ }^{6}$ el cual ha comenzado a moverse del currículum memorístico a otros más creativos y participativos.

\section{Arcatao}

En Arcatao, el programa duró dos semanas, de finales de julio a comienzos de agosto. Los niños seleccionados fueron de una comunidad local, con la asistencia de la directiva de la parroquia y una mujer líder local de confianza, utilizando los mismos criterios de dad, situación financiera y requerimientos de género de La Chacra.

Son nueve participantes, entre las edades de ocho y 13 años, y de primer a sexto grado de escolaridad. La mayoría de los estudiantes son de las colonias Jesús Rojas o La Candelaria, siendo la última un pequeño vecindario en los boscosos escondrijos de la comunidad.

De los nueve, cuatro eran varones y seis, niñas. La participación femenina en el proyecto fue más fácilmente asegurada en razón de su temprana edad; salvo una, todas tenían 11 años. Considerando el corto tiempo para realizar el proyecto, combinado con las sub-estándar habilidades de lectura y escritura de los niños, el centro creativo del currículum y el trabajo de escritura necesario del programa fueron mucho más difíciles de lograr en Arcatao. Al solicitarles una descripción por escrito de cada una de las imágenes que tomaron, los participantes invirtieron horas, no únicamente pensando cómo deseaban describir estas imágenes sino, al mismo tiem- 
po, aprendiendo las palabras y las letras con las cuales escribirlas. Es un logro admirable su habilidad no sólo para manipular una cámara de
$35 \mathrm{~mm}$. al cierre del programa, sino además su dedicación a fortalecer las habilidades de lectura y escritura en tan corto tiempo.

\section{Hablando: Los niños y sus trabajos}

\section{Partiendo}

La emigración en El Salvador de post-guerra ha sido generalmente descrita como una respuesta a las dislocaciones económicas y a las profundas desigualdades sufridas por los pobres desde la firma de los Acuerdos de Paz y las diferentes situaciones, como redes comunitarias, programas especiales de visas, etc., que han facilitado las migraciones (Repak 1995, Mahler 1995, Landolt et al. 1999: 291).

Una economía globalizada, con sede en Estados Unidos, y la abrumadora presencia de las corporaciones multinacionales en $\mathrm{EI}$ Salvador también han estimulado la emigración salvadoreña, al servir como un vínculo estructural, atando la mano de obra nacional a los mercados de Estados Unidos mediante la exposición a las mercancías, rutinas de trabajo y salarios (Repak 60). De la misma forma, también se han involucrado tecnologías de comunicación avanzadas, en la fabricación del "sueño americano", difundiendo mensajes sobre las oportunidades y éxito en Norteamérica, e incrementando simultáneamente la movilidad de los pobres de El Salvador mediante la facilitación de intercambios trans- nacionales, a través del tiempo y el espacio (Marroquín-Parducci 2004, Santillán 2004).

Para los niños dejados por los padres emigrantes en sus países de origen, su comprensión y sentimientos acerca del por qué sus padres no solamente eligen emigrar, sino también porqué deciden hacerlo solos, es la clave para entender cómo estos niños negociarán y responderán a su nueva forma de recibir atención y situación social (Harvard Immigration Project 2001).

\section{Por qué se van}

De acuerdo a los niños de La Chacra, la gente de su comunidad se va para los Estados Unidos por "la falta de empleo", "para sacar a la familia de la pobreza" o porque "el dinero no alcanza". Mediante tales definiciones, han creado una dicotomía entre El Salvador y los Estados Unidos. Una yuxtaposición infundida con el "sueño americano", que pinta El Salvador como el

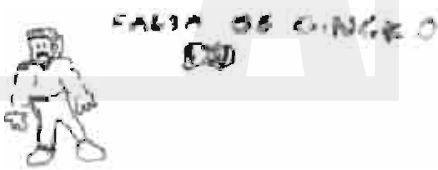

Dibujo de Víctor (La Chacra), que describe porqué las personas migran desde $E I$ Salvador hacia los Estados Unidos 
país atrasado, de pocas oportunidades y altos niveles de pobreza, y los Estados Unidos como una tierra con muchas oportunidades, donde abundan los trabajos y los salarios altos.

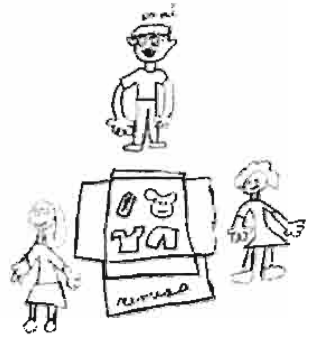

Dibujo de PAMELA (La Chacra), de su familia recibiendo remesas físicas $O$ en especies de su mamá en Estados Unidos

Viendo la decisión de sus padres de irse como más allá de su control, los niños describen a menudo que se sienten muy tristes, cuando al principio conocen los planes de sus padres. Mientras ambas partes imaginan las posibilidades de mejoría en el hogar mediante los ingresos de los padres fuera

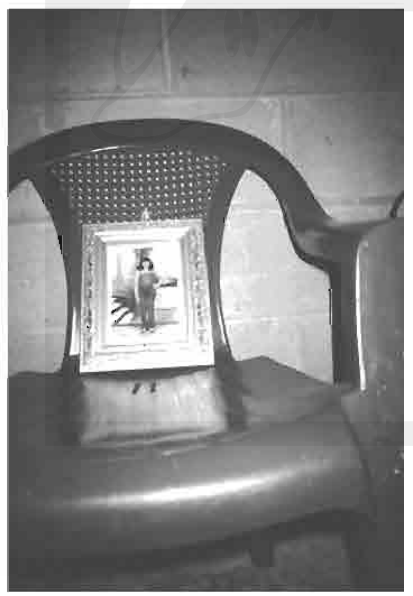

Foto de Yaqui, Arcatao ${ }^{7}$ del país, los valores familiares que impulsan la emigración parental son yuxtapuestos frente a la simultánea pérdida de las personas que cuidan más de ellos (los niños y niñas). La presencia física y emocional de una familia es sacrificada por la provisión de los necesarios recursos económicos, a fin de mejorar su calidad de vida.

Al final, muchos niños creen -mediante la observación de los efectos de la emigración en otras familias y las promesas que sus padres les hacen antes de partir- que la emigración será lo mejor para el beneficio tanto de ellos como a de sus padres que viven fuera.

Sin embargo, en Arcatao, las respuestas $y$ percepciones de los niños de por qué la gente de su comunidad emigra fueron mucho más ambivalentes: las respuestas oscilan desde "Tenía deseos de irse" hasta "La pobreza" y "No hay empleo". Para la mayoría de estos niños, sus
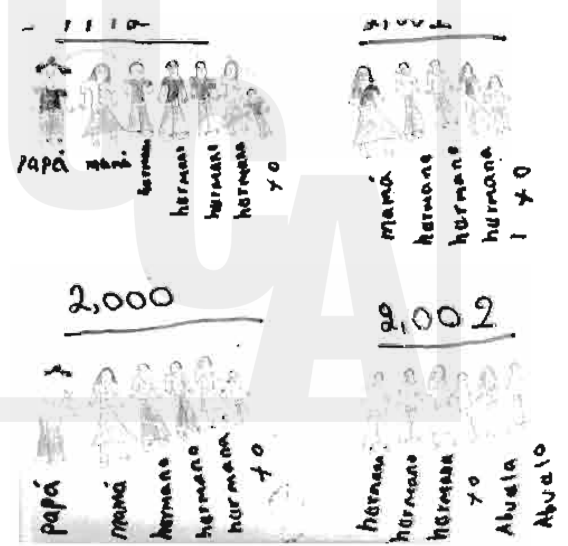

Dibujo de Saúl (Arcatao), en el cual representa los diferentes arreglos familiares desde que el nació 


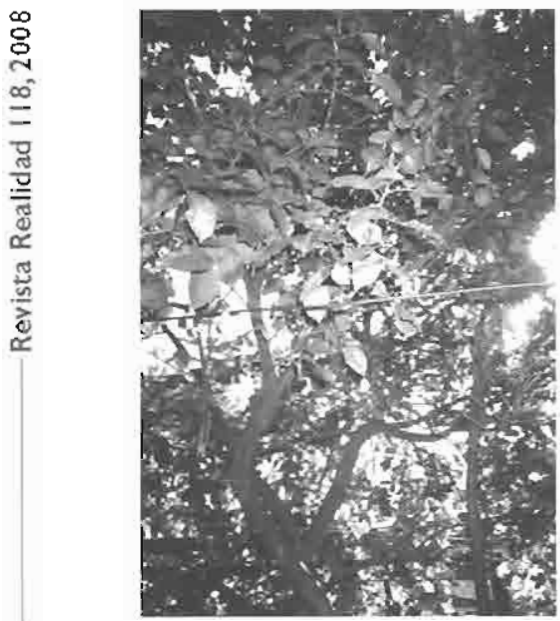

foto de Pamela", La Chacra.

respuestas están condicionadas por el hecho de que sus padres abandomaron Arcatao cuando eran muy pequeños. Muchos no han conocido otra situación de vida o forma de atención y cuidado que la de sus abuelos, familia extensa $u$ hogar de un solo progenitor.

Sobre todo, las estructuras familiares en Arcatao no corresponden a menudo con los paradigmas nucleares tradicionales, sino más bien dependen de una red comunitaria y del apoyo de la familia extensa. La mayoría de estos niños, independientemente del tiempo que tienen los padres de haber emigrado, ya vivían en lo que se llamaría arreglos familiares "extensos" o "alternativos". Si bien esto no niega la importancia del padre o la madre en la vida del niño o su deseo de estar con o saber de él o ella, alivia las transi- ciones en sus cuidados, en caso que su progenitor o progenitora decida irse.

En La Chacra, la forma en la cual los niños racionalizan la decisión de sus padres como en beneficio propio se compara a la ambivalencia de los niños de Arcatao respecto a sus vidas sin su progenitor o progenitora. En ambos, tal conducta parece ser una estrategia para hacerle frente a la situación. A partir de una ambivalencia general que se resuelve en la completa certeza de que la emigración de sus padres fue motivada únicamente por ellos, estas conductas sirven para proteger psicológicamente a los niños, a pesar de cualquier información que podrían tener sobre sus padres formando una nueva familia en Estados Unidos o la inseguridad ante la posibilidad de ser abandonado u olvidado.

La decisión de emigrar no siempre está motivada únicamente por el interés familiar. En La Chacra y Arcatao existe un número de casos, como los de Mario y los hermanos Luz y Moisés. En ambos, una relación problemática entre la madre y el padre fue el punto de ruptura y lo que provocó la emigración de uno de ellos. Es quizá la valorización y el estatus de "heroe" del emigrante salvadoreño lo que brinda la oportunidad, a hombres y mujeres, de abandonar relaciones deterioradas, sin soportar el mismo estigma que en condiciones normales soportarían. 
Entrevistadora: Cuando tu familia se mudó de Panchimalco a La Chacra, ¿quiénes vinieron contigo?

Mario: Venimos a vivir con mi abuela. Venimos yo, mi mamá y mis hermanos.

Entrevistadora: ¿Entonces tu papá se fue antes de que se mudaran?

Mario: Sí, él y mi mamá tuvieron problemas por años. El decidió irse a los Estados Unidos para ayudarnos y hacer una nueva vida.

Entrevistadora: ¿Tu padre está separado de tu madre ahora?

Mario: Bueno, eso creo, ellos todavía hablan por teléfono y él nos manda dinero.

Entrevistadora: ¿Entonces tu mamá dejó La Chacra por sí sola?

Luz: Sí, ella quería irse por un largo tiempo.

Entrevistadora: Entonces, ¿crees que por eso se fue, para conocer los Estados Unidos?

Luz: No, principalmente para ayudarnos aquí en El Salvador. Pero las cosas no andaban bien entre ella y mi papá tampoco. Había problemas y cosas.

Entrevistadora: Pero, ¿te mantienes en contacto con ella, correcto?

Luz: Claro, hablamos seguido, y manda dinero cuando lo necesitamos. 4

Las reflexiones de Luz y Mario atestiguan el crecimiento de la utilidad de la migración para los adultos. Sin embargo, ellos, en tanto niños, permanecen aferrados a la idea de que la decisión de sus padres está totalmente motivada por su deseo de proveer económicamente a ellos y a su familia en El Salvador y que un día todos se reunirán, a pesar de cualquier modificación o reestructuración familiar, como por ejemplo volverse a casar o acompañarse.
En Arcatao, la práctica de "acompañamiento" es más común que el matrimonio. Si bien "acompañarse" es dedicarse y comprometerse a una relación monógama, uno puede fácilmente terminar la unión si las cosas no funcionan. Como tales, las unidades familiares en Arcatao son más fluidas por naturaleza, donde los niños, ya sea que sus padres estén o no casados, a menudo viven con otros parientes. 
Saira: Antes, viví con mi mamá, su nueva pareja y mi media hermana.

Entrevistadora: ¿Dónde vive tu padre?

Saira: Vive con sus padres en otra colonia.

Entrevistadora: Ya veo. Entonces, ¿Cuándo se fue tú estabas con tu mamá?

Saira: No, me fui a vivir con mi tía y mis abuelos. Yo y Dami (su hermana) peleábamos mucho.

a

\section{Por qué nos quedamos}

Mientras los niños han formado su propia comprensión de la emigración de sus padres, también son conscientes de que el viaje al Norte es ilegal y peligroso. Cuando se discute por qué no fueron llevados con sus padres, responden detallando cómo los emigrantes podrían "caer" en su camino, o describiendo la crueldad de los coyotes "estos días".

A pesar de su juventud, se re vela un conocimiento $y$ atención especial sobre el tema. El estar expuestos a las campañas sociales y a los medios de comunicación también condiciona muchas de sus respuestas en relación a la emigración infantil. Según Pamela:

"Yo quería que mi mamá me llevara con ella, pero estaba muy pequeña. Tendré que esperar hasta que sea mayor para que envíe por mi como hizo con mi hermana mayor."

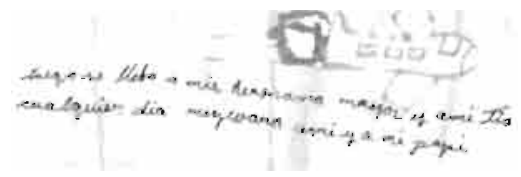

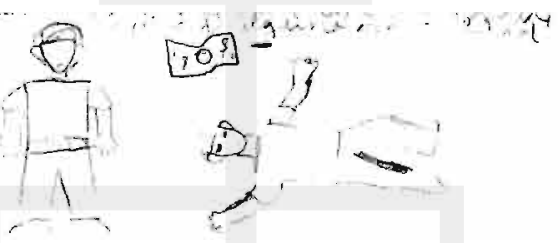

Dibujo de Moisés (la Chacra) en el que representa los peligros de la migración, "un emigrante caído".

En una página del libro elaborado por Pamela sobre la migración de su madre, dice "[...] luego se llevó a mi hermana mayor y a mi tía, cualquier día me llevará a mí y a mi papi."

Los participantes de Arcatao no ven la emigración infantil como ilegal. Al contrario, creen que sus padres enviarían por ellos (ilegalmente) una vez estabilizados en Estados Unidos. Más allá de la expresión de la esperanza de los niños de reunirse con sus padres, los participantes pueden enumerar muchos casos de sus compañeros, que han sido mandados a traer por sus padres desde el exterior. De acuerdo con ellos, mandar a traer a los niños es una práctica común y esperada en Arcatao. 
Adicionalmente, en Arcatao la migración ha adquirido un significado social, como un "derecho de paso", como ocurre en muchas comunidades rurales donde los jóvenes, especialmente hombres, ven a la emigración como una responsabilidad adulta o como un sacrificio.
Una página del libro elaborado por Stanley (La Chacra) describe el viaje de su madre. Dice: "mi mamá se fue y la detuvieron en México, donde a ella le pidieron más dinero (ella tuvo que dar más dinero para cruzar la frontera)".

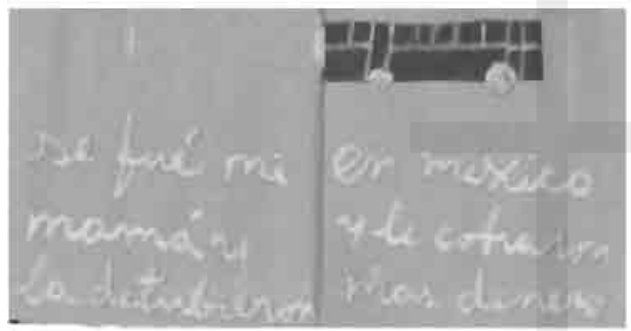

Entrevistadora: Entonces, ¿quiénes son las personas que emigran más a menudo?

Saúl: Los muchachos, cuando cumplen 18.

Entrevistadora: ¿De verdad?, ¿Cómo lo sabes?

Yaqui: Sí, es cierto, cuando cumples 18, puedes ir con un grupo de otras personas. Así es como todos lo hacen.

पt

IMPUGNANDO LO FUNDAMENTAL: TRANSFORMACIONES EN LA UNIDAD FAMILIAR POSTERIOR A LA EMIGRACIÓN
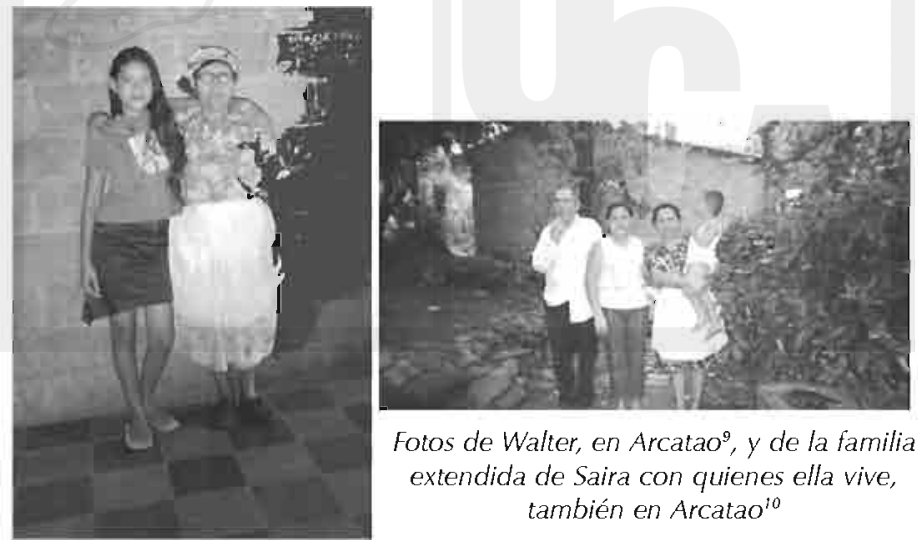

Fotos de Walter, en Arcatao ${ }^{9}$, y de la familia extendida de Saira con quienes ella vive, también en Arcatao ${ }^{\circ}$ 
La familia es, tal vez, la unidad central más importante de apoyo y sobrevivencia en El Salvador. En La Chacra, donde la confianza entre los miembros de la comunidad es bastante baja, la familia es, a menudo, todo lo que uno tiene en momentos de necesidad. Como se describió anteriormente, en Arcatao, las redes de la familia extensa son componentes importantes de las formas de atención y cuidado, así como de apoyo en una sociedad basada en la agricultura.

Por lo tanto, con la emigración de los padres, el problema de la familia y su redefinición se vuelve crucial en cualquier debate relacionado con el bienestar y cuidado de los niños que se han dejado en el país de origen. El discurso contemporáneo y las actitudes sociales han identificado, a menudo, los cambios que experimentan las familias, como "desintegración familiar", donde la ubicación de los niños al cuidado de los miembros de la familia extensa o miembros de la comunidad no corresponde a un modelo de familia nuclear basado en el matrimonio.

Si bien la familia, como una institución legal e histórica en América Latina, ha sido definida como institución patriarcal centrada en la reproducción y el matrimonio monógamo, este ideal no ha correspondido a la realidad de la mayoría de familias latinoamericanas (Kusnesof 2005). Por el contrario, la familia latinoamericana ha tendido a evitar el modelo de parentesco, privado o corporativo, optando por uno más flexible, donde el parentesco y las relaciones de familia se usan en "formas adaptativas y creativas, particularmente en la medida como interactúan aún más fuertemente con la economía globalizada"(2005). A la luz de esta situación y al extenso proceso de negociación, ajuste y reforma que acompaña a la incorporación del niño a una nueva unidad de atención y cuidado, me refiero a los cambios familiares posterior a la emigración como una "transformación", en vez de "desintegración" (véase Westin 1997).

\section{La familia local}

Las transformaciones en la organización familiar, al principio, se dan con mayor facilidad cuando únicamente uno de los padres emigra y el niño queda al cuidado del otro, con el apoyo de otro familiar de la familia extendida. Sin embargo, las cosas se vuelven más complicadas cuando ambos padres emigran. Es en esta situación donde los niños, en un número menor pero creciente de casos, deben vivir con amigos de la familia o miembros de confianza de la comunidad, especialmente si sus parientes (de la familia extendida) ya están cuidando niños de otra familia de emigrantes.

En el caso de los hermanos Luz y Moisés, de La Chacra, vemos que su cuido se convierte en la responsabilidad no solamente de 
los abuelos y otros parientes adultos, sino también de los hermanos mayores. Su madre, abandonada por su padre (con quien viven ellos), depende no de su esposo sino de su hija mayor, para

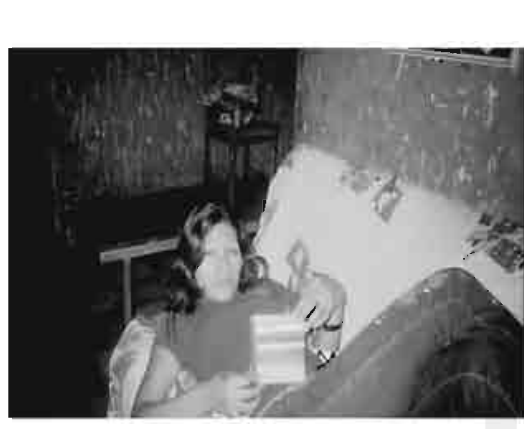

Fotos de Luz" y de Moisés", La Chacra

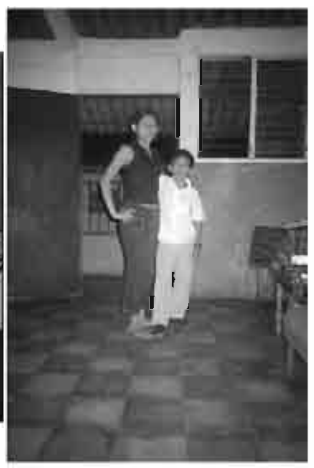

actuales de vida, aquellos que residen con sus abuelos están más contentos con los cambios en el arreglo familiar. Considerando que los padres de estos niños -salvo el de un participante de Arcatao- viven actualmente en el extranjero, los niños perciben estos cambios como medios más estables de preservar la unidad familiar. Esto en comparación con las experiencias de esos niños que continúan viviendo con uno de sus padres, cuya mayoría se ha separado uno del otro desde entonces, iniciando nuevas relaciones familiares en sus respectivos países.

Si bien la mayoría de niños se siente feliz con sus condiciones

Feminización de las responsabilidades de atención, cuido y trabajo reproductivo

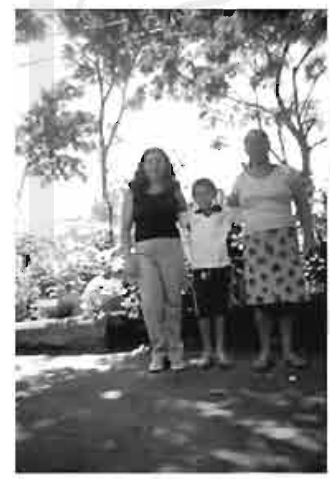

Darwin $^{14}$, Arcatao

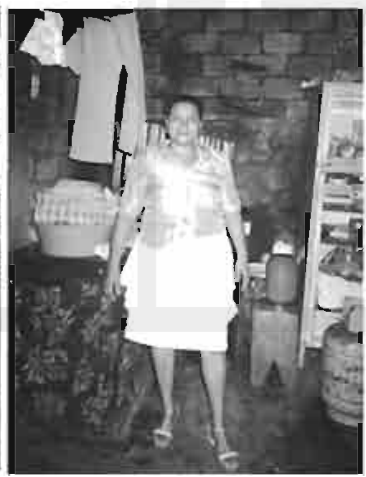

Jonathan ${ }^{15}$, La Chacra

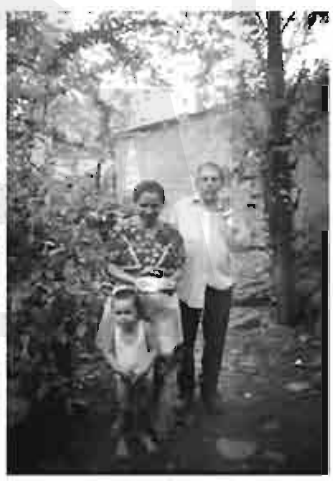

Saira ${ }^{16}$, La Chacra 
Si bien, en ambos sitios del proyecto, la mayoría de los niños vivía con sus madres y su familia extensa materna o solo con la familia extensa materna, tres participantes en La Chacra y dos en Arcatao en realidad vivían en un hogar de un solo progenitor. En Arcatao, los niños fueron llevados al hogar de otros parientes cuando sus padres "se acompañaron con otra". Mientras que en La Chacra, los padres retuvieron un estatus simbólico como familia patriarcal, aunque delegando la mayor parte de trabajo reproductivo y tareas de atención y cuidado a familiares de sexo femenino. En ambos lugares, los hombres padres no asumieron las tareas tradicionalmente femeninas del criado del hijo, en ausencia de su esposa, si bien los hombres padres de La Chacra asumieron una mayor responsabilidad que los de Arcatao. Lo que esto significa es que en casi todos los nuevos arreglos familiares, después de la emigración, la labor reproductiva que requiere la crianza de los niños, es asumida por parientes mujeres, sean estas del área rural o urbana. $Y$ es con estas mujeres con quienes los niños establecen sus lazos más íntimos y cercanos.

Por otra parte, muchas de estas mujeres reciben remesas, con las cuales cuidarán de los niños. Hacerlo solas es una tarea pesada y desalentadora, especialmente para madres solteras y abuelas, que no tienen a nadie con quien compartir sus responsabilidades. El siguiente trabajo de Daniel es muy iluminador de esta dinámica de yuxtaposición entre su exhausta madre y las juguetonas travesuras de su hermano más joven:

Según Thomas-Hope, son los fuertes lazos familiares algo común en las familias de las clases populares, lo que permite a los padres emigrar, dejando a sus hijos, sin ningún estigma, al cuidado de parientes, amigos o vecinos. Sin embargo, cuando este mismo sistema se quiebra, la mayoría de padres temen que se ponga a prueba, pues los niños se vuelven más propensos al abuso y al rechazo (2002).

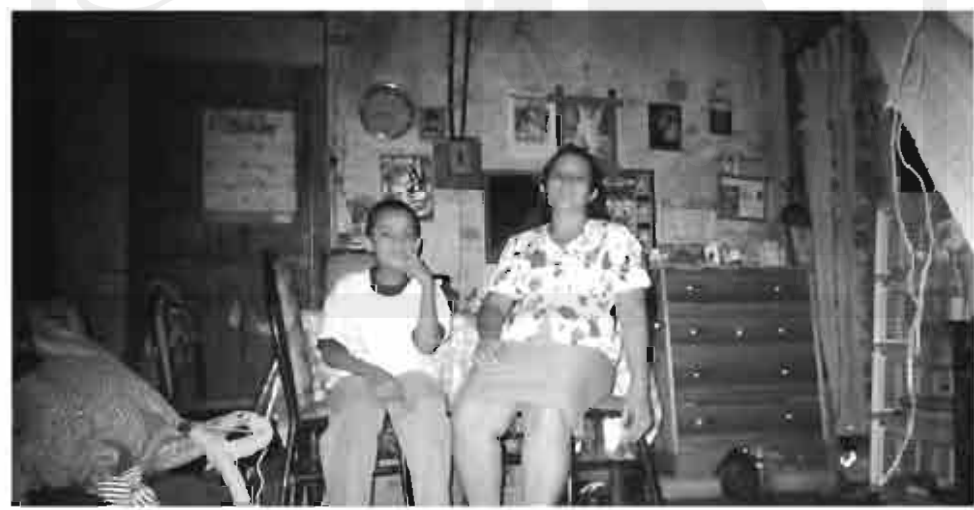


El siguiente extracto es de una entrevista con Yeri, de cuya madre apenas sabe que vive en Suecia y el padre, que nunca conoció, radica desde entonces en Estados Unidos. Está claro que nadie se ha responsabilizado por ella, y, según parece, el enorme distanciamiento entre ella y su madre contribuye al constante desplazamiento y al abuso que ha sufrido.

Entrevistadora: La hermana me dijo que acabas de regresar a Arcatao, ¿dónde estuviste entonces?

Yeri: Estaba viviendo con mi otra abuela, pero murió.

Entrevistadora: Lo siento mucho, Yeri. ¿Van bien las cosas para ti ahora? Yeri: Sí, están bien.

Entrevistadora: Entonces, cuando tu mamá se fue primero, ¿te fuiste a vivir con tu abuela?

Yeri: Estaba viviendo con mi otra abuela, pero murió.

Entrevistadora: Lo siento mucho, Yeri. ¿Van bien las cosas para ti ahora? Yeri: Sí, están bien.

Entrevistadora: Entonces, cuando tu mamá se fue primero, ¿te fuiste a vivir con tu abuela?

Yeri: No. Es así: Mi mamá se fue, cuando yo nací, a trabajar en casas de gente rica, en San Salvador. Me quedé aquí. Mi papá se fue, entonces me fui a vivir con otro Familiar en otra comunidad, pero me pegaban mucho y la mujer siempre me gritaba y le dije a mi mamá y me trasladaron a la casa de mi abuela. La primera. Ella murió y por eso me pasaron aquí.

Aparte de la reorganización de la unidad familiar en el país de origen, la capacidad de la unidad familiar original de resistir la separación, a largo plazo y a gran distancia, de la mayoría de emigraciones es un fenómeno relativamente nuevo. Antes, se asumía que cuando los emigrantes se iban, lo hacían definitivamente.
Sin embargo, actualmente la tecnología global y la creciente movilidad han facilitado los intercambios transnacionales entre países "hogares y anfitriones" (Santillán 2004). La salvadoreñaestadounidense Karla Lazo describe la experiencia de su propia niñez en El Salvador: 
"Mis padres vinieron a Estados Unidos poco tiempo después de haber nacido yo, y vine a reunirme con ellos a la edad de siete años. Sabia de mis padres únicamente por fotografía, tome en cuenta que esto sucedió en los 80; recibir llamadas $y$ chatear en Internet no era posible en esa época. Ellas me ayudaron a recordar a mis padres y a evitar que perdiera la esperanza."

Afortunadamente, la tecnología de las comunicaciones es accesible a los niños en el programa y juega un rol crucial para mantenerlos en contacto con sus seres queridos en el exterior. Tales intercambios transnacionales, ya sean físicos, monetarios o sociales, han facilitado, además, el surgimiento de lo que Ilamaré "la familia transnacional".

\section{Familia entre fronteras}

Adoptar y mantener los lazos familiares entre fronteras, como Karla revela en su testimonio, requiere dedicación y el mantenimiento de la esperanza por parte de los seres queridos, tanto en El Salvador como en el exterior. Mediante conversaciones telefónicas, telegramas, correo electrónico o mensajes transmitidos de persona a persona, ambas partes hacen lo que pueden por mantenerse informados uno del otro, a pesar de la distancia. Ambos están permanentemente entretejidos en lo que Basch ha denominado un "campo social transnacional", donde los pensamientos, sentimientos y preocupaciones son intercambiados sin restricciones, a lo largo del espacio y el tiempo.

De acuerdo con los niños, el factor más importante en la comunicación, entre los miembros de una familia, es el teléfono. Esto está comprobado por el gran número de fotos que documentan su uso en ambos sitios. Como se puede ver en las siguientes páginas, es más común en el área rural de Arcatao que la gente compre tarjetas de saldo telefónico, para usarlas en los

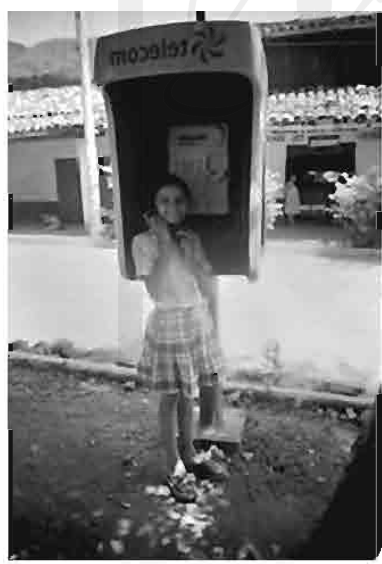

Saira ${ }^{17}$, Arcatao.

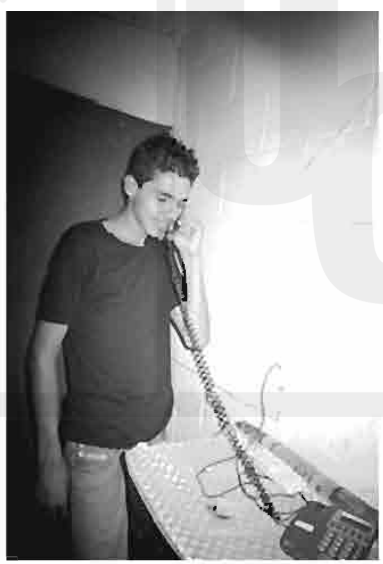

Wendy', La Chacra.

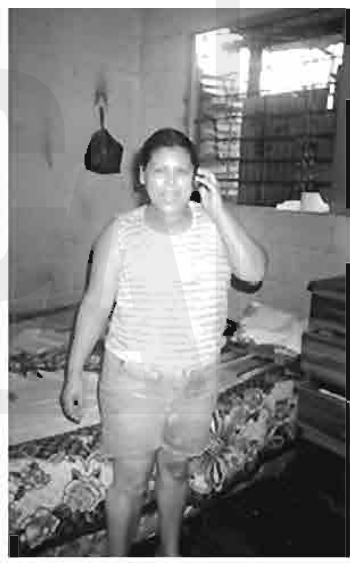

Jonathan ${ }^{19}$, La Chacra 

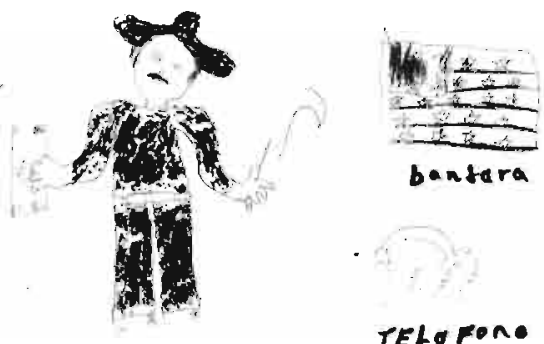

Una ilustración sobre la emigración de su papa, hecha por Wilfredo (Arcatao).

teléfonos públicos, mientras que líneas fijas y teléfonos celulares son más comunes en la zona urbana de La Chacra. Sin embargo, el uso del celular en Arcatao está aumentando, luego de que Telecom instalara una torre para usuarios de la municipalidad el año pasado.

Mientras la mayoría describe un horario para recibir y realizar

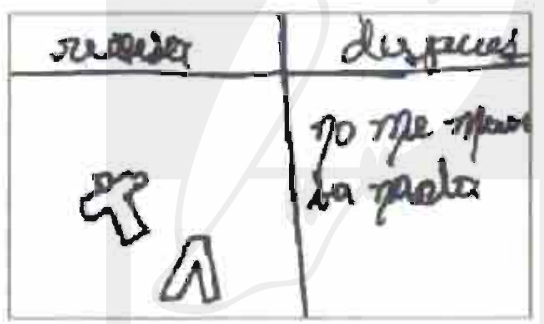

Ilamadas a sus seres queridos fuera, no siempre es posible mantener la capacidad de resistencia ante la separación. Con el tiempo, muchas familias dejan de recibir remesas o comunicación de su progenitor o progenitora emigrante en el exterior.

El siguiente trabajo hecho por Javier (La Chacra) es un ejercicio en el cual los estudiantes dibujaron cómo era la vida "antes" de la emigración de su padre o madre y "después". La mayoría de niños dibujó zapatos viejos y ropas andrajosas en el "antes", y juegos de televisión y refrigeradoras en el "después". Mientras que Javier dibujó cosas similares en el dibujo de "antes"; $y$ en el espacio de "después" escribió, "no me mandaba nada".

Si bien él trató de bromear sobre su dibujo cuando le preguntaron otros estudiantes, Javier estaba tan avergonzado por su situación, que nunca volvió a clases, a pesar de los incentivos y la solicitud de los demás participantes. De forma similar se desarrolló la discusión entre las medias hermanas Dami y Saira (de Arcatao), durante la entrevista.

Entrevistadora: Entonces, ¿te mantienes en contacto con tu padre?

Dami: Sí, nos llama de vez en cuando

Entrevistadora. Es fantástico, ¿puede enviar dinero o artículos a la familia desde Estados Unidos?

Dami: Sí, nos envía 50 dólares mensuales.

Saira: ¡Mentirosa! Tú sabes que ya no te manda nada.

Dami: (Llorando) Eres tan cruel. ¿Por qué tienes que avergonzarme? 
A menudo los niños usan el valor de los artículos y el dinero que les envían sus padres, o la pura novedad de que éstos son "americanos", para impresionar a aquellos cuyos padres no son capaces de darles lo mismo. Una remesa social, el surgimiento de "la clase de los emigrantes" no se limita a los adultos; también es reforzada y recreada por gente joven.

Más aún, cuando un niño deja de recibir remesas de su padre o madre en el exterior, es la primera señal de que los peores temores de abandono pueden ser ciertos. A menudo, el manejo que tiene el emigrante en sus operaciones -poder costear las llamadas telefónicas y el envío de remesas- significa que cuando las llamadas y los envíos cesan, el niño es dejado con muy pocos recursos para recontactarse con él o ella. El proceso de entristecimiento de esta persona es generalmente muy confuso y doloroso, ya que para el niño, su padre está presente psicológicamente, aunque físicamente ausente (Boss 1999).

Si bien el "abandono" por el progenitor(a) fue más común para los niños de Arcatao, el aspecto económico relacionado con él fue menos devastador, ya que la mayoría de ellos recibe remesas de varios parientes en el exterior, no sólo de sus padres. En La Chacra, sin embargo, los niños dependen principalmente del progenitor o progenitora que tienen en el exterior, $y$ la pérdida de este ingreso generalmente deja a la familia tratando de encontrar nuevas formas de reponer la pérdida, lo que se resuelve, la mayor parte de las veces, a través de un nuevo matrimonio o el compartir responsabilidades y costos de vida con parientes.

\section{NIÑOS Y REMESAS: INTERCAM- BIOS SOCIALES, MONETARIOS $Y$ FÍSICOS ENTRE FAMILIAS A TRA- VÉS DE LAS FRONTERAS}

Como salvadoreños en el exterior, los emigrantes participan en el de "ni de aquí ni de allá" de la ciudadanía transnacional o "desterritorializada", sus niños experimentan también un desplazamiento similar, ya que los seres queridos permanecen presentes emocionalmente mediante los recuerdos y la comunicación continua, pero físicamente ausentes de su vida diaria. A fin de mantener fuertes los contactos interfamiliares y cumplir las promesas hechas a sus familiares y comunidades hogareñas, los emigrantes utilizan caminos transnacionales para el envío de remesas. Sean éstas de índole física, monetaria o social, las remesas son la manera fundamental de mantener y nutrir la familia transnacional.

\section{Remesas monetarias y físicas}

En años recientes, los envíos monetarios han cobrado el primer plano en virtud de su utilidad económica y el tan necesario capital que proporcionan a los pobres del país, la posibilidad de inversión local por los acaudalados emigrantes en el exterior y su utilidad colectiva como un mecanismo de desarrollo local (véase Gammage 2005). 
Los estudiantes de La Chacra y Arcatao reciben un promedio de 50 a 100 dólares americanos mensuales, mediante servicios de envío, un giro o transferencia bancaria. Según los estudiantes de ambas comunidades, solamente recibían "envíos" cuando su familiar estaba "recién

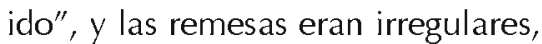
tanto en tiempo como en cantidad. Con el incremento en la recepción de remesas (ya que cuando los salarios de los emigrantes se acumulan, se paga la deuda del ingreso ilegal y se estabiliza la economía), los niños dicen que sus familias se cambian a los bancos porque "te dan más". Para los niños de Arcatao, esto significa que deben viajar a la cabecera del departamento, Chalatenango, a recoger su remesa, mientras los de La Chacra tienen acceso a una diversidad de bancos en el área metropolitana.

En La Chacra, donde cuatro de los diez participantes tienen padres que ya no están juntos o en buenos términos, la remesa es recibida y distribuida por terceras personas, a menudo un miembro de la familia extensa del emigrante o un hermano mayor. En todos estos casos, el emigrante en el exterior evita poner el dinero en manos de alguien en quien ya no confía. Por el contrario, lo envían a alguien que indudablemente garantizará que llegue a sus beneficiarios, los niños. En todos los casos, la comunicación telefónica no sólo permite a las familias comunicarse entre sí, sino también para que el remitente pueda comprobar sobre cómo el dinero enviado ha sido invertido por el receptor y el niño.

Antes, cuando ella acostumbraba enviarnos, solía llamarnos por teléfono y darnos un $P I N$, para que pudiéramos retirar el dinero. Ahora, vamos con mi hermana a retirar el dinero al banco cuando ella llama.

\section{-Luz, La Chacra.}

Mi abuela recibe el dinero de mi papá y me da a mí y mis hermanos lo que necesitamos. El antes no enviaba a todos, pero ahora mi mamá está con otro hombre.

\section{-Víctor, La Chacra.}

Para retirar el dinero que mandan, tienes que tomar el bus para Chalatenango. Me

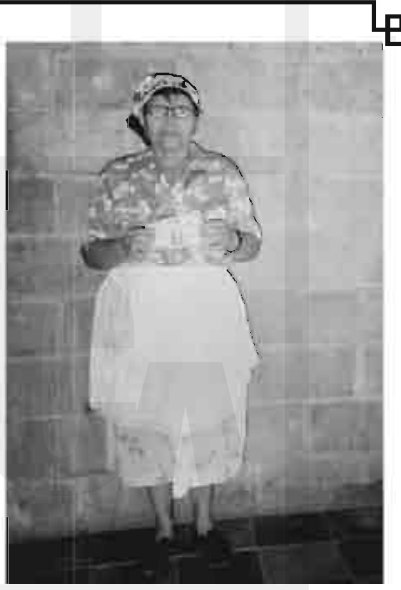

Foto de Walter ${ }^{20}$, Arcatao gusta ir, pero las colas en el banco son casi siempre muy largas y me canso. 


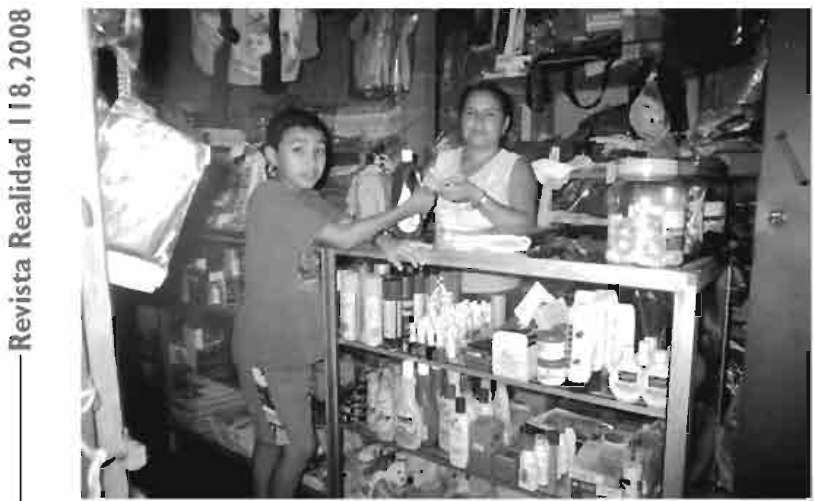

Foto de Dami, Arcatao

que garantiza la seguridad alimenticia, el pago de gastos escolares y en algunas ocasiones para las "extras" como para comprar "unas chucherías" -como el padre de Pamela, quien tiene11 años (La Chacra) describe los momentos en que él puede darle dinero a ella para comprar pequeñas chucherías. Sus imágenes cuestionan las

La manera cómo se gastan estas remesas ha sido agudamente criticada, tanto por académicos como por miembros de la comunidad, especialmente aquellos que no provienen de hogares receptores de remesas (Marroquín-Parducci 2004). Típicamente, tales críticas han tendido a enfocar la posible utilidad de las remesas como víctima del "malgasto" y "consumo" por una clase pobre que las utiliza de forma ineficiente.

Sin embargo, las fotografías de los niños subrayan un uso más significativo de las remesas como un intercambio de bienes $y$ dinero

asunciones acerca de "la inversión productiva" de las remesas, así como también las demandas clasistas de tal actitud, sobre cómo el pobre puede o debe gastar su dinero.

\section{Educación}

Literatura reciente identifica las remesas como un mecanismo para el desarrollo, también ha comenzado a explorar las posibilidades para impactar en el desarrollo humano, citando el intercambio transnacional de ideas, dinero y conocimiento como una potencial estrategia de "ganancia de cerebros" para El Salvador (Andrade-Eekhoff 1999).

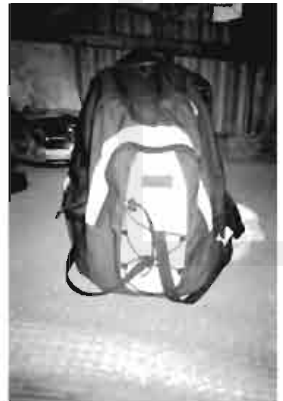

Mario $^{22}$, La Chacra

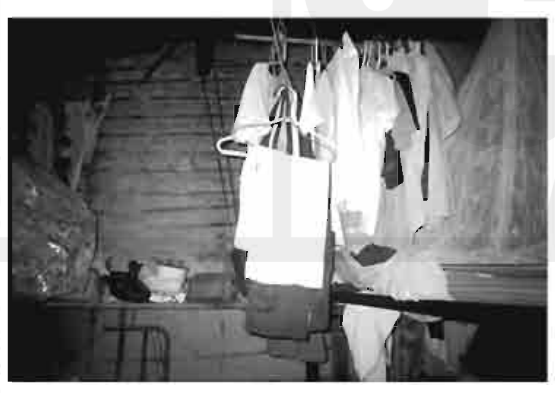

Daniel23, La Chacra

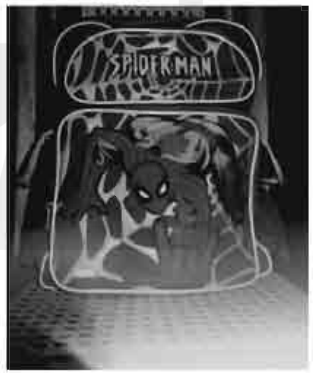

Moisés ${ }^{24}$ La Chacra 
Las fotografías anteriores describen cómo los niños y sus familias han hecho de la educación una prioridad, en lo referente a gastos de remesas.

Es importante destacar que todas las imágenes que tratan de remesas y educación fueron tomadas por estudiantes varones en La Chacra, mientras ninguna de las niñas participantes, ni los varones en Arcatao, tomó fotografías que reflejaran este tema en especial. Se necesitaría de investigación adicional, a fin de examinar las posibles diferencias en cuanto a inversión de remesas entre la educación de los muchachos y las muchachas, así como las diferencias en gastos de educación entre comunidades urbanas y rurales.

Sobreviviendo: Remesas en la vida diaria

Para la mayoría de niños y sus familias, las remesas no son dinero "extra" para ahorrar o gastar, sino un ingreso muy necesitado, usado muy a menudo para cubrir gastos diarios del hogar y recibos por servicios. Según la madre de uno de los participantes en La Chacra,

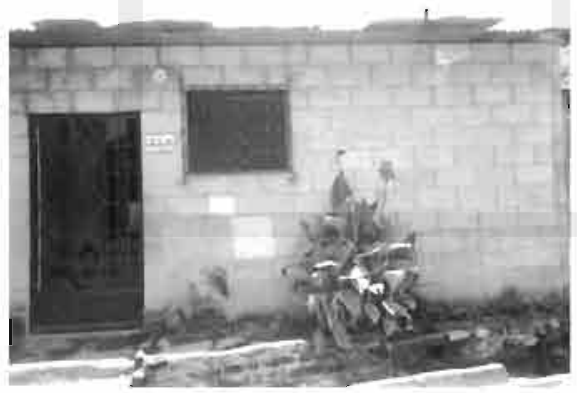

Daniel $^{25}$, La Chacra.

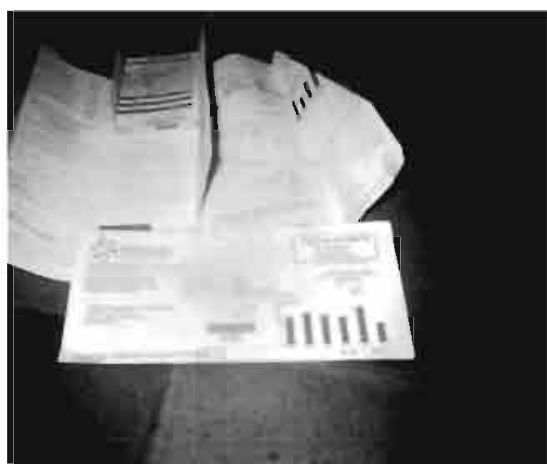

Foto de Luz, La Chacra

antes de recibir remesas ellos pasaban sin electricidad un mes, pero pagaban el agua y viceversa en los meses siguientes. Ahora, con el dinero que recibe, la familia es capaz de pagar ambas cuentas $y$ hasta ha adquirido una línea telefónica y un refrigerador.

La compra de muebles, electrodomésticos -especialmente cocinas eléctricas, refrigeradoras, equipos de audio y televisión-, además de mejoras en el hogar, es una gran prioridad para las familias de ambas comunidades. En La Chacra, a causa de la informalidad y vulnerabilidad de la mayoría de hogares (la mayoría de casas construidas en Arcatao durante el período de

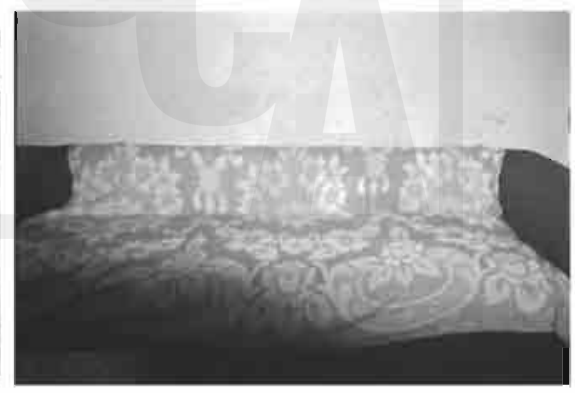

Pamela ${ }^{27}$, La Chacra. 
postguerra, son casas planificadas, hechas de bloques) también se invierte mucho en la reparación y mejoramiento de la infraestructura del hogar, así como el alumbrado o el techo. Además, la compra de ciertos bienes, especialmente equipos de sonido y video, no satisface únicamente un propósito, sino que además conlleva una tangible expresión de clase y "progreso" entre los hogares receptores de remesas.

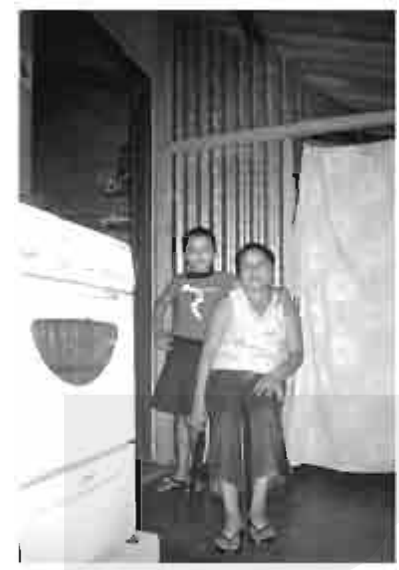

Dami28, Arcatao.

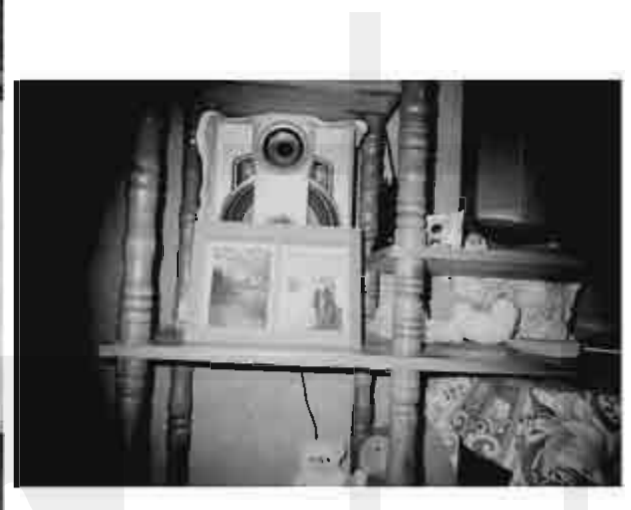

Darwin $^{29}$, Arcatao.

Mientras tales compras eran comunes en ambos sitios, la compra de electrodomésticos y otros bienes de alto costo fueron documentados extensamente por los jóvenes de La Chacra; en cambio los participantes de Arcatao se orientaron a fotografiar bienes de bajo costo, como ropa y alimentos.

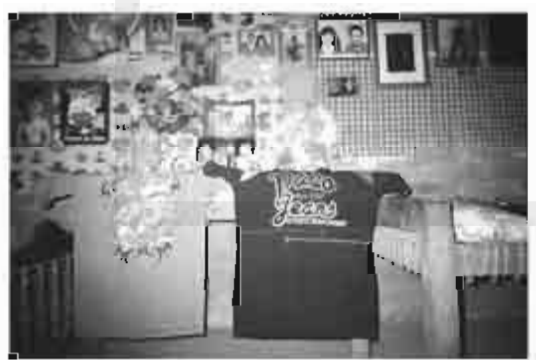

Saúlio, Arcatao.
Es importante destacar que en Arcatao la mayoría de ropa que se envía a los niños, por parte del progenitor o progenitora que vive en el exterior, se hace por medio de un viajero local (véase Gammage, 2004), amigos emigrantes del padre o la madre que vive fuera y que han regresado de visita o por correo ordinario.

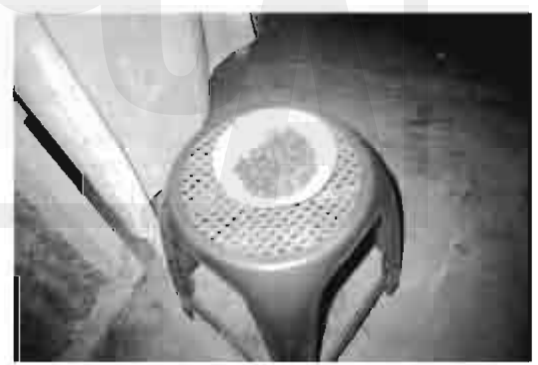

Dami ${ }^{31}$, Arcatao. 


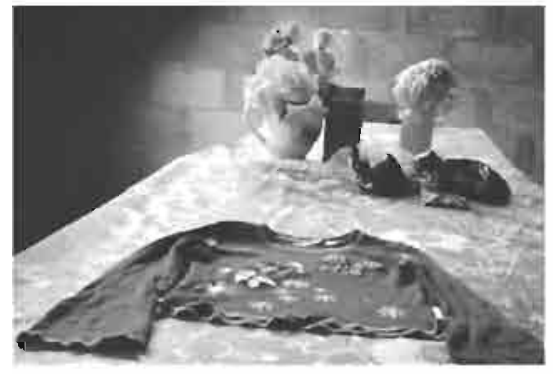

Yaqui ${ }^{32}$, Arcatao.

Si bien esta práctica también existe en La Chacra, la recepción y envío de artículos por medio de mensajeros informales de la comunidad es menos común allí, donde la mayoría de pertenencias son compradas con el giro o la remesa que recibe la familia del emigrante del exterior.

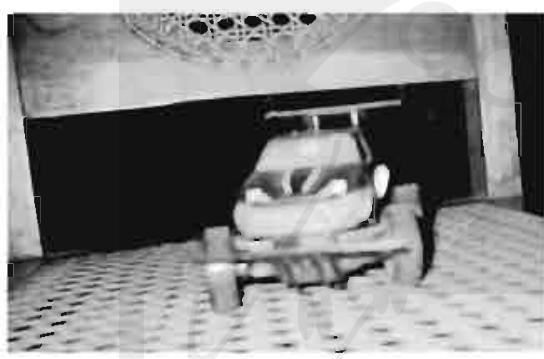

Stanley ${ }^{34}$, La Chacra.

No obstante la importancia de los artículos adquiridos mediante el dinero de la remesa, para los niños el pensamiento y afecto representado por las remesas físicas son la codificación simbólica de la constante preocupación y amor por ellos. Tales regalos hablan de sus necesidades, no solamente en cuanto a amor sino también en lo relativo al juego y al entretenimiento, a pesar de las inhóspitas condiciones en las

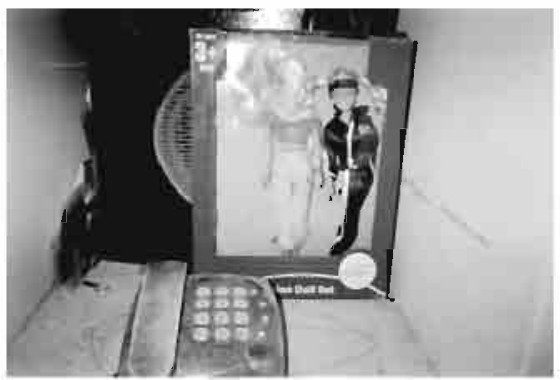

Pamela ${ }^{33}$, La Chacra.

que puedan vivir y de las otras responsabilidades económicas de sus familias, tanto en El Salvador como en Estados Unidos deben afrontar.

\section{La migración y las remesas sociales}

Dinero, regalos y conversación no son los únicos intercambios entre estos niños y sus seres amados en el exterior. Existen, además, transmisiones sociales entre familias y comunidades, que son facilitadas por los flujos globales existentes, como parte de un proceso continuo de difusión cultural (Levitt 1998: 937). Si bien los niños no tomaron ninguna fotografía que pudiera atestiguar este fenómeno, ofrezco aquí un breve recuento de las historias que compartieron conmigo, así como mis propias observaciones sobre ambos lugares.

En Arcatao, la remesa social más manifiesta era la forma en la que los niños valoraban y deseaban aparatos y artículos americanos. Se daba una conversación interminable entre los niños acerca de quién iba a recibir el juguete más nuevo o lo último en tecnología de los Estados 
Unidos, quién sabía más sobre Los Angeles y Nueva Jersey, hasta qué artículo le pedirian al padre o madre que enviara la próxima vez que viniera el viajero o viajera. Entre los niños que viven en hogares recep. tores de remesas, tanto en Arcatao como en La Chacra, existe un muy delicado, aunque inmisericorde, sistema de clases y competencia, fundado en el consumo de ideas y artículos americanos. Su conducta, sin embargo, no es simplemente el resultado de un transmisión transnacional de los valores consumistas americanos, sino la confluencia de diferentes ideas acerca de la superioridad de los bienes de "allá", dándole sentido a las nuevas expresiones transnacionales de parentesco y devoción, además de la necesidad de darle significado a los bienes materiales, los cuales de otra manera no serían accesibles en el ambiente de pobreza en el que viven.

Sobretodo, para las muchachas de Arcatao, al igual que los que Levitt examina entre los mirafloreños de República Dominicana y Estados Unidos, han adoptado ciertos estilos de vestuario que sus propias madres han encontrado $y$ enviado $a$ El Salvador. Cuando se le pregunta a Paty sobre sus botas de cuero negras hasta las rodillas, responde:

"Mi mami me las envió y el mismo par a mi hermana Zuma. También tengo un vestido que combina con effas. Son como las que visten allá [...] siempre nos envian nuevas prendas cada año, para hucir en las fiestas [patronales]."

Similar a la historia de Paty el siguiente dibujo de Yaqui refleja cómo las transmisiones sociales de los estilos de vestido están desafiando las normas de género tradicionales del pueblo sobre el vestuario "femenino" apropiado. En él, describe cómo era la vida "antes" $y$ "después" de que su madre emigrara, dibujándose ella misma vestida tradicionalmente con una blusa y falda larga en el dibujo del "antes", y una camisa y pantaletas en el de "después".

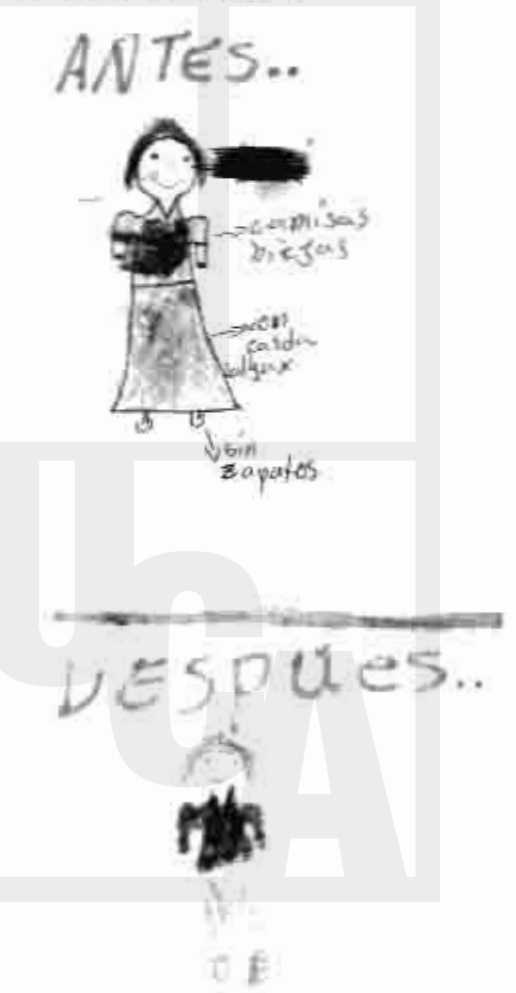

Dibujo de Paty sobre el antes y el despues Nosotros, los que quedamos atr is

Digitalizado por Biblioteca "P. Florentino Idoate, S.J." Universidad Centroamericana José Simeón Cañas 
Si bien las expresiones físicas, relativas a las remesas sociales, fueron menos aparentes en La Chacra, donde existe un mayor acceso a los productos americanos $y$, por tanto, menos probable de ser enviados del exterior, en ambas comunidades la emigración ha tenido un notable efecto en la forma en que las jóvenes participantes negocian los roles y expectativas de género tradicionales.

Mientras los cambios en el vestuario son notables, situaciones como las de Luz y Moisés, cuyo principal responsable es una hermana mayor, quien de forma antitradicional se encarga del hogar, administra los gastos, va a la universidad y trabaja fuera de casa, no únicamente altera los valores normativos acerca de los roles de género aceptable, sino que además genera nuevos "sistemas de prácti$\mathrm{ca}^{\prime \prime}$ con los cuales establecer esos valores (Levitt 1996).

Con la recepción de remesas, distribuida de manera desproporcionada entre las mujeres de El Salvador (cuya tendencia en la forma de gastar se ha dicho que favorece la inversión en sus niños y en la familia -véase Gammage et al.2005-), los nuevos roles de la mujer podrían eventualmente mejorar la aceptación social de los comportamientos no tradicionales de las mujeres y las oportunidades futuras para sus hijas y hermanas.

\section{Identidad y Desarrollo: Una mirada hacia adelante}

U $\mathrm{n}$ estudio reciente del Proyecto de Inmigración de la Universidad de Harvard reveló que el $85 \%$ de los niños inmigrantes en los Estados Unidos experimenta una separación de sus progenitores durante el proceso migratorio (Proyecto de Inmigración de Harvard 2001). De este grupo, los centroamericanos obtuvieron una de las tasas de separación más alta $(80 \%)$, y el mayor tiempo de separación promedio, $47 \%$, de los niños pasaron 5 años o más. Para muchos de estos niños, enviados años después de que sus padres han dejado El Salvador, su sueño de reunirse con sus familias es a menudo no tan fácil o idílico como esperaban (Nazario 2002).
Nuestro programa siempre culmina en una encuesta similar, donde se le pregunta a los niños qué se imaginan haciendo dentro de cinco años y dónde se imaginan viviendo. En cada comunidad, cada niño dijo que querían vivir y trabajar en El Salvador, pero cada niño dijo, además, que quería estar con sus familias, sin importar donde estuvieran. Las negociaciones sobre la identidad, la familia y la comunidad entre fronteras están jalando a estos niños en diferentes direcciones, pero sobre todo hacia los Estados Unidos. Al crecer y comenzar a enfrentar los mismos desafíos económicos y las barreras relativas al empleo que sus padres también enfrentaron, 
esta atracción irá volviéndose más fuerte, especialmente para los niños de las áreas rurales.

Según la Convención de las Naciones Unidas sobre los Derechos del Niño, los niños tienen el derecho a beneficiarse de la seguridad social, a contar con una identidad cultural y nacional y, más específicamente, el derecho a una familia aún cuando sus padres no sean capaces de ofrecerla. La emigración crónica, fomentada por la pobreza en el país de origen, les niega estos derechos inalienables, truncándoles sus oportunidades futuras y sus sueños.

Garantizar estos derechos de la niñez demandará el interés y la conciencia de todos los sectores de la sociedad, acerca de las experiencias y las desventajas sistemáticas que estos niños enfrentan, así como la dedicación permanente de estos grupos por buscar nuevas políticas y prácticas que podrían darle a estos niños igualdad de oportunidades de realizar todas sus potencialidades como ciudadanos salvadoreños.

Los asuntos más urgentes destacados por estos niños requieren de marcos legales que incorporen y protejan las unidad de la familia no tradicional en la que viven; que el Ministerio de Relaciones Exteriores para Salvadoreños en el Exterior tome a estos niños con seriedad y los coloque al alcance de la diaspórica comunidad; que la educación y la inclusión se extiendan a las clases populares de El Salvador; que la educación integral acerca de la inversión de las remesas en desarrollo humano sea el objetivo de las familias en comunidades con altos índices de emigración y de la diáspora misma; $y$, finalmente, que el Estado establezca un mecanis-

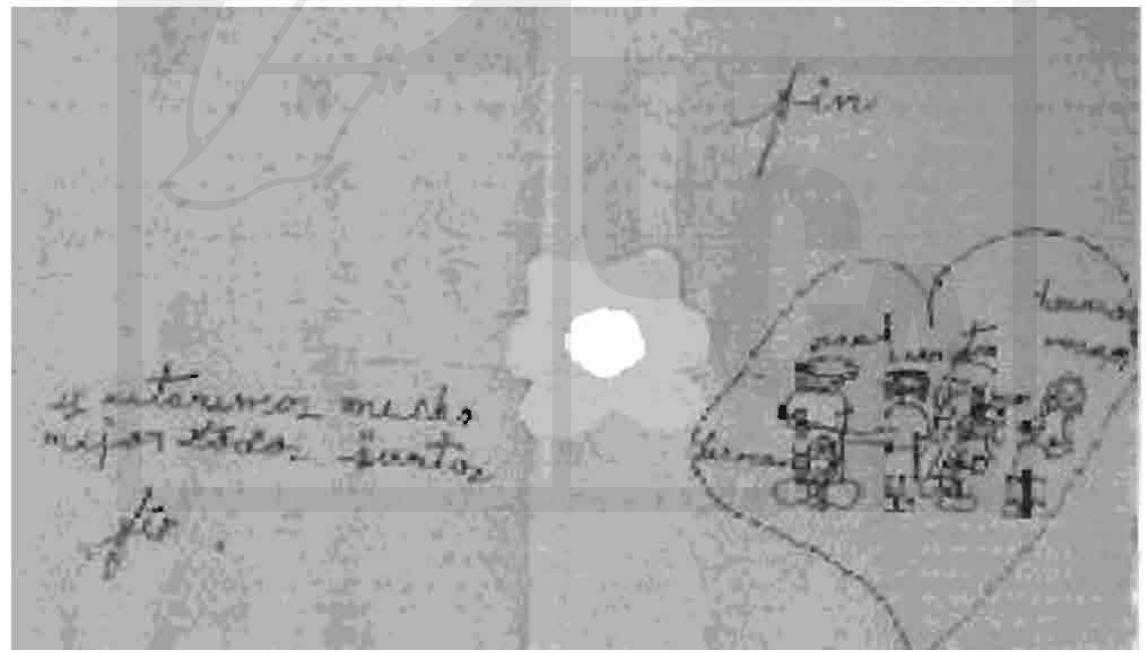

Pamela, La Chacra 
mo por medio del cual responda a aquellos niños que están en riesgo o preocupados con sus reacomodos de vida. Esta lista puede y debe ser trabajada mediante discusiones entre las comunidades de la gente afectada, los mismos niños y los miembros de todos los sectores involucrados. La circulación y compartimiento de estas fotografías y testimonios infantiles es un importante comienzo en el inicio de este diálogo.
En una reciente visita a una institución gubernamental, un funcionario destacó que en El Salvador la gente se va porque son la materia de exportación más valiosa del país. La calidad e integridad de estas fotografías y testimonios por escrito demuestra, sin embargo, que la riqueza de El Salvador, de hecho, radica en su propia gente.

El final del relato de Pamela sobre la emigración de su madre dice:

\section{"...y estaremos mejor todos juntos. Fin".}

\section{BIBLIOGRAFÍA}

- Anderson, Benedict. 1991. Imagined Communities: reflections on the origin and Spread of Nationalism. Rev. edition. London: Verso.

- Andrade-Eekhoff, K. "El intercambio transnacional de conocimientos: Posibilidades a través de la Migración Salvadoreña". Conectándonos al futuro de El Salvador. 199. www.conectando.org.sv/Estrategja/EstudioMigración.htm

- Andrade-Eekhoff, K. "Ante retos locales, acciones globales: la migración laboral y los nuevos retos para la formulación de políticas en un mundo transnacional". Fundación Canadiense para las Américas. 12004. http://www.focal.ca.

- Basch, Linda, N. Glick-Schiller and C. Szanton Blanc eds. 1994, Nations Unbound: Trnas- national Projects, Postcolonial Predicaments and Deteritorialized nation-States, Langhorne, PA: Gordon an Breach.

- Boss, P. (1999). Ambiguous loss: learning to live with unresolved grief. Cambridge, MA: Harvard University press.

- Freire, Paulo. Pedagogy of the Opprressed. New York: Continuum International Publishing Group, 2003.

- Gammage, Sarah and Alison Paul, Melany Machado, Manuel Benítez. "Ender, Migration and Transnational Communities". A draft report prepared for the Inter-American Foundation. April, 2005. Posted at http://www.rci. rutgers.edu/ migrate1/GMTCFinalDraft.pdf.

Giroux, Henry A. Disturbing Pleasure, Learning Popular Culture. New York: Routledge, 1994.

- Harvard Immigration Project. "85\% of Immigrant Children 
Experience Separations During Migration". Harvard Graduate School of Education. June 29, 2001.

- Holiday, David. "El Salvador's "Model" Democracy". Current History. February (2005):77-82.

- Kuznesof, Elizabeth A. "The House, the Street, Global Society: Latin American Families and Chilhood in the Twenty-First Century". Journal os Social History, Fairfaix: Summer 2005. Vol. 38 (4) 859-972.

- Levitt, Peggy. "Social Remittances: Migration Driven Local-Level Forms of Cultural Diffusion". International Migration Review. Vol. 32 (4) Winter 1998. Center for Migration Studies of New York.

- Landolt, Patricia and Lilian Autler, Sonia Baires. "From Hermano Lejano to Hermano Mayor: the dialectics of Salvadoran transnationalism". Ethnic and Racial Studies Vol. 22 (2) March 1999, Routledge. 292-314

- Mahler, Sarah. 1995. American Dreaming: Immigration Life on the Margins. Princeton NJ: Princeton University Press.

- Marroquín Parducci, Amaparo. Exploración de patrones culturales y formas de comunicación surgidas por las migraciones. Working paper. San Salvador: UCA, 2004.

- Nazario, S. (2002, October 6). Entirque's Journey. Los Angeles Times, rieved December 2006 from http:/www.latimes.com/ news/specials/enrique/la-fg-firstson iasep29,0,7492292.story? Coll=la=nav-specials-enrique\#

- Pottinger, Audrey. "Children's Experience of Loss by Parental Migration in Inner-City HJamaica". American Journal of Orthopsychiatry. Vol. 75 (4) October, 2005, p485-496.

- Repak, Terry. Waiting on Washington, Central American Workers in the Nation's Capital. Philadelphia: Temple University Press, 1995.

- Sobrino, J. et al. La voz de los sin voz, la palabra viva de monseñor Romero. San Salvador: UCA Editores, 1980.

- Solomon-Godeau, Abigail. Photography at the Dock, Essays on Photographic History, Institutions and Practices. Minneapolis: University of Minnesota press, 1991.

- Santillán, Diana. Renegotiating Identities: Transnational Links, Diaspora Discourse, and Panethnic Communities. Destination D.C. Working Paper. Washington DC, December, 2004. posted at http://www.rci.rutgers. edu/ migrate1/researchPapers/ SantillanWorkingPaper4.pdf.

- Thomas-Hope, E. (2002). Caribbean Migration. Mona, Jamaica: University of the West Indies Press.

Westin, Kath. Families We Choose. New York: Columbia University Press, 1997. 
Walter: "Esta es una foto de mi abuela porque ya no hay nadie que le ayude a hacer oficio."

1 Traducción del inglés al español realizada por Oswaldo Caminos y Lilian Vega.

2 Esto de acuerdo con el Director de Prevención de Maras Juveniles de la comunidad. Ver también "parroquia de la Chacra pide paz para jóvenes de la comunidad" en www.diariocolatino.com/nacionales/detalles. asp? $\mathrm{News}$ ID $=9945$

3 Para mayor información ver el artículo del Diario de Hoy "Mejoran Los Manantiales" de Guadalupe Hernández en http://www.elsalvador.com/noticias/2004/06/10/metro/met1.asp y "Vientos de cambio en La Chacra" por Wendy Ramos en http://www.laprensagrafica.com/ gransansalvador $/ 20030904$ /gransansalvador1.asp

4 Este esfuerzo fue fuertemente apoyado por el grupo espańol Manos Unidas.

5 Para mayor información ver el estudio de Aquiles Montoya “El Desarrollo Económico Comunitario, Diagnóstico Socieconómico de cien comunidades" disponible en http://www.uca.edu.sv/publica/ued/ eca-proceso/ecas_anter/eca/595art3. html

- Para mayor información ver el artículo del Diario de Hoy "Con fe y alegría por El Salvador” por Ricardo Guevara en http://www, elsalvador. $\mathrm{com} /$ noticias $/ 2003 / 08 / 25 / \mathrm{vida} /$

7 Yaqui: "Yo tomé esta foto de mis padres porque me hacen falta."

- Pamela: "Este árbol era una semilla cuando mi mamá se fue y hoy es muy grande." papá (sin descripción, tomada por Damisela).

18 Wendy: "Esta foto yo la tomé porque los migrantes se comunican con la familia."

19 Jonathan: "Yo tomé esta foto porque mi mamá está hablando con mi papá."

20 Walter: "Aquí está mi abuela con el dinero que le manda."

21 Damo: "Así compramos las cosas que necesitamos con la remesa."

22 Mario: "Yo tomé esta foto porque él me mandó el maletín y me sirve para llevar los cuadernos a la escuela."

23 Daniel: “[uniformes] Yo tomé esta foto porque mi papá se fue para mandar dinero para ir a la escuela." 


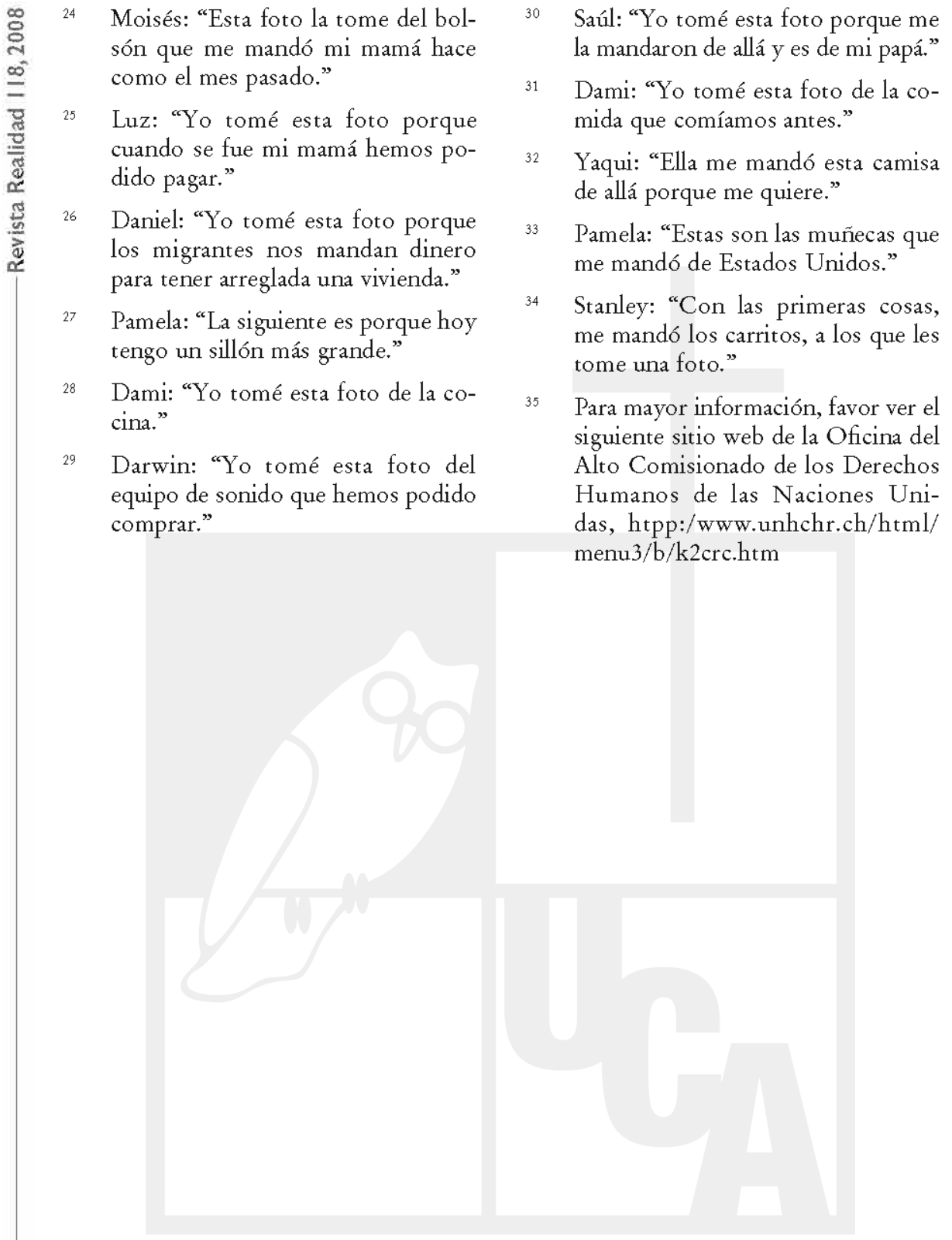

